Manchester et al from Denver reported a series of 257 pregnancies which were complicated by suspected fetal abnormality on ultrasonography. ${ }^{1}$ Thirty seven per cent of the infants born had additional anomalies not detected by prenatal ultrasonography, and the authors concluded that prenatal diagnoses based on ultrasonography were remarkably accurate but were insensitive to associated anomalies in individual cases. Our study confirms this, a revised diagnosis being made in $53(40 \%)$ of such cases.

We believe that examination of midtrimester fetuses by a clinical geneticist is a worthwhile service and improves diagnosis, which in turn benefits the diagnostic teams and parental counselling. It is best carried out by a clinician experienced in dysmorphology, used to normal variations in the appearance of fetuses at various stages in gestation, and familiar with rare dysmorphic syndromes. The collaboration of cytogeneticists and paediatric pathologists is important in defining the full extent of the anomalies in order to arrive at the final post-termination diagnosis, on which the parents will base their future reproductive decisions.
We thank Dr T Andrews, regional cytogenetic service, and his staff and Dr A J Barson, department of paediatric pathology, University of Manchester, and his staff for their skilled work and cooperation.

1 Manchester DK, Pretorius DH, Avery C, et al. Accuracy of ultrasound diagnoses in pregnancies complicated by suspected fetal anomalies. Prinal Diagn 1988;8:109-17.

2 Donnai D. The management of the patient having fetal diagnosis. Bullicre's Clin Obstet Gynaecol 1987:1:737-45.

3 Winter RM, Knowles SAS, Bieber FR, Baraitser M. The pathological examination of the infant and examination of the placenta. In: The malforme t examination of the infant and examination of the placenta. In: $7 /$ c

fetus and stillbirth. Chichester: John Wiley and Sons, 1988:40-68

Kelling JW, ed. Place of structured request forms in prenatal pathology. In: Fetal and neonatal pathology. London: Springer Verlag, 1987:3.

5 Bieber FR, Petres RF, Bieber JM, Nance WE. Prenatal detection of a familial nuchal bleb simulating encephalocele. Birth Defects 1979;15:51-61.

6 Salonen R, Herva R, Reijo N. The hydrolethalus syndrome: delincation of it 'new' lethal malformation syndrome based on 28 patients. Clin (ienct 1981;19:321-30.

7 Meckel S, Pessarge E. Encephalocele, polycystic kidnevs and polydacty is an autosomal recessive trait simulating certain other disorders: the Mecket syndrome. Ann Genet 1971:14:97.

8 Carey JC, Greenbaum B, Hall BD. The OEIS complex (omplaticule exstrophy, imperforate anus, spinal defects). Birth Defects 1978;156B:253-63.

9 Jones KL Smith's recognisable paterns of human mulfor, $156 \mathrm{~B}: 25363$. Philadelphia: W B Saunders, 1988:210-1

(Accepted 29 November 1989)

\title{
Microalbuminuria as predictor of increased mortality in elderly people
}

\author{
Else Marie Damsgaard, Anders Frøland, Ole Dan Jørgensen, Carl Erik Mogensen
}

Abstract

Objective-Correlation of the urinary albumin excretion rate and the risk of death among elderly subjects.

Design-216 Subjects aged 60-74 whose urinary albumin excretion rate had been determined were followed up 62-83 months later.

Setting-Municipality of Fredericia, Denmark.

Subjects-223 People who had been selected as control subjects for diabetics found during a systematic screening for diabetes of all people aged 60-74 living in the municipality of Fredericia, Denmark. Of these subjects, 216 had an extensive clinical and biochemical examination within a few weeks of selection.

Main outcome measure-Death.

Results - The median urinary albumin excretion rate was $7.52 \mu \mathrm{g} / \mathrm{min}$. Eight of those with a rate below the median died compared with 23 with a rate equal to or greater than the median $(p=0.0078)$. The median albumin excretion rate in the 31 who died was $15.00 \mu \mathrm{g} / \mathrm{min}$. Cardiovascular disease was the most common cause of death in both groups. A multivariate regression analysis of survival data was performed using the proportional hazards model. Besides albumin excretion rate, male sex, serum creatinine concentration, and hypertension were found to be of prognostic value.

Conclusions-The association between the albumin excretion rate and mortality that has been described in recent years in patients with diabetes mellitus may be present in elderly people in general, even when other known risk factors are taken into account.

Correspondence to: Dr Else Marie Damsgaard, Institute of Clinical Genetics, J B Winsløwsvej 17, 5000 Odense $\mathrm{C}$, Denmark. present when other risk factors such as male sex, age, obesity, ischaemic heart disease, hypertension, smoking, and raised blood lipid concentrations are taken into account. ${ }^{135}$ Microalbuminuria is also associated with hypertension ${ }^{9}$ and increased cardiovascular morbidity in people who are not diabetic. ${ }^{510}$ We followed up a cohort of subjects drawn from the population of Fredericia ${ }^{11}$ who were recruited to serve as controls for a cohort of diabetics aged 60-74 found during population screening. We followed up the subjects who were not diabetic for 62 to 83 months, or to death, and evaluated their urinary albumin excretion and other possible risk factors for death.

\section{Subjects and methods}

From 1 February 1981 to 31 October 1982 all people aged 60-74 living in the municipality of Fredericia, Denmark, were invited to have their blood glucose concentration measured after fasting overnight. The participants were also interviewed about a possible history of diabetes. Details of the sampling procedure and characteristics of those who did not respond have been described. ${ }^{11}$ We invited 5699 people to participate, $5292(92.9 \%)$ of whom accepted. Of these, 236 gave a history of diabetes. All the people screened were numbered consecutively, and for each diabetic subject a control was defined as the person with the nearest following number who was of the same sex and age (within one year) and whose fasting blood glucose concentration was below $7 \cdot 0 \mathrm{mmol} / \mathrm{l}$. Altogether 223 $(94.5 \%)$ controls consented to further examination. Table I gives the age and sex distributions of this control group (the study population) and the corresponding total population of the municipality. All subjects were asked to have an extensive clinical and biochemical examination.

The blood and urine of subjects were sampled not later than three weeks after the initial screening. Venous blood obtained after subjects had fasted was tested for glucose, serum creatinine, triglyceride, total 
cholesterol, very low density lipoprotein, low density lipoprotein, and high density lipoprotein concentrations and for $\mathrm{C}$ peptide concentration before and six minutes after an intravenous injection of $1 \mathrm{mg}$ of glucagon. ${ }^{12}$ Blood glucose concentration was measured by a hexokinase method, ${ }^{13}$ plasma lipoproteins by centrifugation and electrophoresis, ${ }^{14}$ and $\mathrm{C}$ peptide concentrations by radioimmunoassay. ${ }^{15}$ Creatinine was determined by Jaffe's kinetic method with a Beckman Astra analyser. Urine tests were performed within one week of the blood sampling and the subjects were again fasting or had had a light meal and had drunk at most $500 \mathrm{ml}$ of water during the preceding four hours. After voiding they drank $200 \mathrm{ml}$ of water, waited for one hour, and then voided again. This second urine

TABLE I-Sex and age distributions (expressed as numbers (percentages) of study population and corresponding total population of municipality of Fredericia on 1 fanuary 1982

\begin{tabular}{ccccccccc}
\hline & \multicolumn{3}{c}{ Study population } & & \multicolumn{3}{c}{ Total population } \\
\cline { 2 - 4 } $\begin{array}{c}\text { Age } \\
\text { years })\end{array}$ & Men & Women & Men:women & & Men & Women & Men:women \\
\hline $60-65$ & $28(31)$ & $36(27)$ & $0 \cdot 78$ & & $1128(42 \cdot 5)$ & $1189(37 \cdot 2)$ & 0.95 \\
$65-69$ & $28(31)$ & $45(34)$ & $0 \cdot 62$ & & $858(32 \cdot 4)$ & $1046(32 \cdot 7)$ & $0 \cdot 82$ \\
$70-74$ & $33(37)$ & $53(40)$ & $0 \cdot 62$ & & $666(25 \cdot 1)$ & $964(30 \cdot 1)$ & $0 \cdot 69$ \\
\hline Total & 89 & 134 & 0.66 & & 2652 & 3199 & 0.83 \\
\hline
\end{tabular}

TABLE II - Cause of death among subjects whose urinary excretion rate had been determined

\begin{tabular}{|c|c|c|c|c|c|}
\hline Case No & Sex & $\begin{array}{l}\text { Age at } \\
\text { death } \\
\text { (year) }\end{array}$ & $\begin{array}{l}\text { Albumin } \\
\text { excretion } \\
(\mu \mathrm{g} / \mathrm{min})\end{array}$ & Cause of death & $\begin{array}{l}\text { Source of } \\
\text { information }\end{array}$ \\
\hline 1 & M & 68 & $55 \cdot 0$ & Myocardial infarction & Necropsy \\
\hline 2 & $M$ & 72 & $14 \cdot 4$ & Myocardial infarction & Necropsy \\
\hline 3 & $\mathrm{M}$ & 77 & $55 \cdot 9$ & Myocardial infarction & Necropsy \\
\hline 4 & $\mathrm{M}$ & 78 & $86 \cdot 0$ & Myocardial infarction & Necropsy \\
\hline 5 & $\mathrm{M}$ & 73 & $32 \cdot 5$ & Myocardial infarction & Hospital record \\
\hline 6 & $\mathrm{~F}$ & 67 & $4 \cdot 4$ & Myocardial infarction & Hospital record \\
\hline 7 & M & 79 & 343.6 & Myocardial infarction & Hospital record \\
\hline 8 & $\mathrm{~F}$ & 78 & $8 \cdot 7$ & Heart disease & Death certificate \\
\hline 9 & F & 75 & $5 \cdot 0$ & Found dead. Previous myocardial infarction & Death certificate \\
\hline 10 & M & 72 & $21 \cdot 8$ & Found dead. Previous myocardial infarction & Death certificate \\
\hline 11 & M & 68 & $34 \cdot 7$ & Found dead. Previous myocardial infarction & Death certificate \\
\hline 12 & M & 72 & $4 \cdot 3$ & Found dead. Heart disease presumed & Death certificate \\
\hline 13 & $M$ & 72 & 71.5 & Cerebral haemorrhage & Hospital record \\
\hline 14 & $\mathrm{~F}$ & 79 & $2 \cdot 0$ & Cerebral thrombosis & Death certificate \\
\hline 15 & $\mathrm{~F}$ & 66 & $41 \cdot 1$ & Subarachnoid haemorrhage & Necropsy \\
\hline 16 & $M$ & 76 & $21 \cdot 6$ & Bronchitis & Hospital record \\
\hline 17 & M & 80 & $11 \cdot 8$ & Carcinoma of the prostate & Hospital record \\
\hline 18 & $\mathrm{~F}$ & 74 & $25 \cdot 1$ & Carcinoma of the stomach & Hospital record \\
\hline 19 & M & 70 & $18 \cdot 2$ & Carcinoma of the urinary bladder & Necropsy \\
\hline 20 & M & 76 & $5 \cdot 0$ & Carcinoma of the urinary bladder & Necropsy \\
\hline 21 & M & 63 & $10 \cdot 5$ & Carcinoma of the urinary bladder & Hospital record \\
\hline 22 & M & 75 & $2 \cdot 1$ & Carcinoma of the urinary bladder & Hospital record \\
\hline 23 & $\mathrm{~F}$ & 76 & $4 \cdot 3$ & Carcinoma of the colon & Hospital record \\
\hline 24 & M & 75 & $12 \cdot 6$ & Carcinoma of the lung & Hospital record \\
\hline 25 & $M$ & 69 & $160 \cdot 6$ & Carcinoma of the pancreas & Hospital record \\
\hline 26 & $\mathrm{~F}$ & 74 & $12 \cdot 6$ & Lymphatic leukaemia & Hospital record \\
\hline 27 & $M$ & 77 & $17 \cdot 0$ & Suicide & Death certificate \\
\hline 28 & $\mathbf{F}$ & 76 & $162 \cdot 3$ & Found dead. No information on previous disease & Death certificate \\
\hline 29 & $M$ & 73 & $6 \cdot 2$ & Found dead. No information on previous disease & Death certificate \\
\hline 30 & $M$ & 70 & $13 \cdot 5$ & Found dead. No information on previous disease & Hospital record \\
\hline 31 & $\mathrm{~F}$ & 67 & $15 \cdot 0$ & Unknown. Died abroad & \\
\hline
\end{tabular}

TABLE III - Characteristics of continuous variables studied (populations were divided at median for log rank tests on mortality)

\begin{tabular}{|c|c|c|c|c|c|}
\hline & \multirow[b]{2}{*}{ Median (quartiles) } & \multirow[b]{2}{*}{$\begin{array}{l}\text { Total No } \\
\text { of subjects } \\
\text { examined }\end{array}$} & \multicolumn{2}{|c|}{$\begin{array}{l}\text { No of subjects who } \\
\text { died with values: }\end{array}$} & \multirow[b]{2}{*}{$\begin{array}{c}\mathrm{p} \text { Value of } \\
\text { log rank } \\
\text { test }\end{array}$} \\
\hline & & & $\begin{array}{l}\text { Equal to or } \\
\text { above the } \\
\text { median }^{\star}\end{array}$ & $\begin{array}{l}\text { Below the } \\
\text { mediant }\end{array}$ & \\
\hline Age & $68 \cdot 1(63 \cdot 6,71 \cdot 3)$ & 223 & 20 & 15 & NS \\
\hline Fasting blood glucose $(\mathrm{mmol} / \mathrm{l})$ & $4 \cdot 55(4 \cdot 22,4 \cdot 91)$ & 223 & 23 & 12 & $0 \cdot 03$ \\
\hline Stimulated C-peptide $(\mathrm{nmol} / \mathrm{l})$ & $1.38(0.98,1.77)$ & 223 & 19 & 16 & NS \\
\hline \multicolumn{6}{|l|}{ Urinary albumin excretion rate } \\
\hline$\mu \mathrm{g} / \mathrm{min}$ & $7 \cdot 52(4 \cdot 77,14 \cdot 85)$ & 216 & 23 & 8 & 0.002 \\
\hline Body mass index $\left(\mathrm{kg} / \mathrm{m}^{2}\right)$ & $24 \cdot 90(22 \cdot 44,27 \cdot 68)$ & 223 & 17 & 18 & NS \\
\hline Triglycerides $(\mathrm{mmol} / \mathrm{l})$ & $1.21(0.88,1.65)$ & 223 & 23 & 12 & $0 \cdot 001$ \\
\hline Total cholesterol $(\mathrm{mmol} / \mathrm{l})$ & $6.57(6.03,7 \cdot 40)$ & 223 & 21 & 14 & NS \\
\hline \multicolumn{6}{|l|}{ Very low density lipoproteins } \\
\hline$(\mathrm{g} / \mathrm{l})$ & $1.40(1.00,1.99)$ & 223 & 18 & 17 & NS \\
\hline Low density lipoproteins $(\mathrm{g} / \mathrm{l}$ ) & $4 \cdot 91(4 \cdot 29,5 \cdot 67)$ & 223 & 18 & 17 & NS \\
\hline High density lipoproteins $(\mathrm{g} / \mathrm{l})$ & $3 \cdot 80(3 \cdot 10,4 \cdot 90)$ & 223 & 12 & 23 & NS \\
\hline Serum creatinine $(\mu \mathrm{mol} / \mathrm{l})$ & $92 \cdot 6(82 \cdot 3,101 \cdot 8)$ & 223 & 29 & 6 & $0 \cdot 0001$ \\
\hline \multirow{2}{*}{$\begin{array}{l}\text { Creatinine clearance }(\mathrm{ml} / \mathrm{min}) \\
\left(1.73 \mathrm{~m}^{2} \text { surface } \text { area }\right)\end{array}$} & & & & & \\
\hline & $80.55(68.95,96 \cdot 40)$ & 216 & 19 & 16 & NS \\
\hline
\end{tabular}

$\star$ Proportional hazards analysis score $=1$.

tProportional hazards analysis score $=0$. specimen was frozen and later analysed for albumin by radioimmunoassay ${ }^{16}$ and for creatinine.

The participants were asked to complete a Rose questionnaire ${ }^{17}$ on the symptoms of angina pectoris and were interviewed about their smoking habits. Their height and weight were measured without shoes and overcoat, and blood pressure was measured in the right arm with an electronic sphygmomanometer (Kontron 3000) after the subjects had rested supine for 10 minutes. Diastolic blood pressure was taken as that at the disappearance of the Korotkoff sounds (phase V). A 12 lead resting electrocardiogram was recorded with the subjects sitting before and after exercise and was interpreted according to the Minnesota code. ${ }^{17}$ A six lead exercise electrocardiogram was recorded at minute intervals during a bicycle test in the sitting position. Men started at a power of $50 \mathrm{~W}$ and women at $25 \mathrm{~W}$, the workload being increased stepwise until subjects were exhausted or stopped the test for other reasons. ${ }^{18}$

Body mass index was calculated as weight $(\mathrm{kg}) /(\text { height }(\mathrm{m}))^{2}$, and hypertension was defined as a systolic blood pressure $\geqslant 160 \mathrm{~mm} \mathrm{Hg}$, diastolic pressure $\geqslant 95 \mathrm{~mm} \mathrm{Hg}$, or treatment for hypertension. Ischaemic heart disease was diagnosed if a person had one or more of the following signs: angina pectoris; previous myocardial infarction verified during admission to hospital; important changes in the resting electrocardiogram (Minnesota code 1.1-1.3, 4.1-4.4, $5.1-5.3,7.1)$; ST segment changes of $\geqslant 1 \mathrm{~mm}$ during exercise; or ST items, T items, or left bundle branch block after exercise (Minnesota code 11.1-5, 12.1-4, 14.1).

All urine specimens were tested for the presence of leucocytes by a test strip (Cytur). ${ }^{19}$ If the strip yielded a positive result a fresh urine specimen was examined by microscopy and the urine was incubated for 48 hours if more than three leucocytes were seen. Urinary tract infection was diagnosed if the urine contained more than $10^{5}$ bacteria $/ \mathrm{ml}$.

All subjects were traced through the national register at the beginning of 1988 . If a subject had died before 31 December 1987 the date of death was recorded and information on the cause of death was sought from hospital records, necropsy records, and death certificates. The observation period was defined as the number of days from the date of the population screening in 1981-2 to the date of death or 31 December 1987.

\section{STATISTICAL METHODS}

Statistical analysis was performed with $\chi^{2}$ tests, log rank tests, and proportional hazards analyses. ${ }^{20}$ For the log rank tests and proportional hazards analyses the continuous variables (see table III) were divided into two groups: those with values equal to or above the median (scored 1) and those below (scored 0 ). The discontinuous variables (see table IV) were grouped into classes such that being male, smoking, and having ischaemic heart disease and urinary tract infection scored 1 and the opposite scored 0. Although the categorisation of the continuous variables in the proportional hazards analysis may have led to some loss of statistical power, it avoided the assumption of linearity and kept the scoring simple. Additional tests showed that the continuous variables were non-linear and that no simple scoring was possible.

Proportionality was checked by stratification and observing a constant vertical difference (independent of time) between plots of estimates of the logarithm of the integrated hazard for each stratum. The risk factors considered in the proportional hazards model were all entered into a first model. This model was reduced by removing the variable causing the least change in significance. This principle was continued 
TABLE IV-Characteristics of discontinuous variables (populations were divided according to stated groups for log rank tests on mortality)

\begin{tabular}{|c|c|c|c|c|}
\hline & $\begin{array}{l}\text { Total No of } \\
\text { subjects } \\
\text { examined }\end{array}$ & $\begin{array}{l}\text { No (\%) of } \\
\text { subjects in } \\
\text { each group }\end{array}$ & $\begin{array}{c}\text { No who } \\
\text { died }\end{array}$ & $\begin{array}{l}\mathrm{p} \text { Value of } \\
\text { log rank test }\end{array}$ \\
\hline Sex & 223 & & & $<0.0001$ \\
\hline $\begin{array}{l}\text { Male } \\
\text { Femalet }\end{array}$ & & $\begin{array}{r}89(40) \\
134(60)\end{array}$ & $\begin{array}{l}24 \\
11\end{array}$ & \\
\hline Ischaemic heart disease & 223 & & & 0.02 \\
\hline $\begin{array}{l}\text { Present } \\
\text { Absent }\end{array}$ & & $\begin{array}{r}87(39) \\
136(61)\end{array}$ & $\begin{array}{l}20 \\
15\end{array}$ & \\
\hline Hypertension & 223 & & & 0.0002 \\
\hline $\begin{array}{l}\text { Present }{ }^{\star} \\
\text { Absent } \dagger\end{array}$ & & $\begin{array}{r}71(32) \\
152(68)\end{array}$ & $\begin{array}{l}20 \\
15\end{array}$ & \\
\hline Urinary infection & 223 & & & NS \\
\hline $\begin{array}{l}\text { Present* } \\
\text { Absent } \dagger\end{array}$ & & $\begin{array}{c}16(7) \\
207(93)\end{array}$ & $\begin{array}{r}4 \\
31\end{array}$ & \\
\hline Smoking & 223 & & & \\
\hline $\begin{array}{l}\text { Present* } \\
\text { Formerly or nevert }\end{array}$ & & $\begin{array}{l}108(48) \\
115(52)\end{array}$ & $\begin{array}{l}19 \\
16\end{array}$ & NS \\
\hline
\end{tabular}

TABLE $\mathrm{V}-$ Results of proportional hazards analysis

\begin{tabular}{lcccc} 
Risk factor & $\begin{array}{c}\text { Regression } \\
\text { coefficient }\end{array}$ & $\begin{array}{c}\text { Standard } \\
\text { error }\end{array}$ & p Value & $\begin{array}{c}\text { Odds ratio } \\
\text { (95\% confidence interval) }\end{array}$ \\
\hline Urinary albumin excretion rate & 1.080 & 0.415 & 0.009 & $2.94(1.31$ to 6.64) \\
Serum creatinine & 1.425 & 0.513 & 0.006 & $4.16(1.52$ to 11.36$)$ \\
Male sex & 0.824 & 0.424 & 0.051 & $2.28(0.99$ to 5.23$)$ \\
Hypertension & 1.119 & 0.376 & 0.003 & $3.06(1.46$ to 6.40) \\
\hline
\end{tabular}

until no further variables could be removed without causing a significant change of the model. The models were compared by using likelihood ratio tests $(5 \%$ significance level).

\section{Results}

The urinary albumin excretion rate was determined in 216 subjects, 31 of whom died during the observation period. The median excretion rate was $7.52 \mu \mathrm{g} / \mathrm{min}(25 \%$ and $75 \%$ centiles 4.77 and $14.85 \mu \mathrm{g} / \mathrm{min}$ ). Among the 107 subjects with excretion rates below the median value eight died, and among those with values equal to or above the median 23 died $\left(\chi^{2}=7.08, p=0.0078\right)$. Four subjects excreted more than $200 \mu \mathrm{g}$ albumin/min, and one of these died during the observation period. The median excretion rate in those who died was $15.00 \mu \mathrm{g} / \mathrm{min}(25 \%$ and $75 \%$ centiles 6.20 and $41 \cdot 10 \mu \mathrm{g} / \mathrm{min}$ ). The figure shows the survival curves for the groups with low and high excretion.

Information on the cause of death was obtained for all those who died, except one who died abroad (table II). Eight of 15 subjects who had an excretion rate below $15.00 \mu \mathrm{g} / \mathrm{min}$ died from cerebrovascular disease or suddenly from coronary artery disease, as did 10

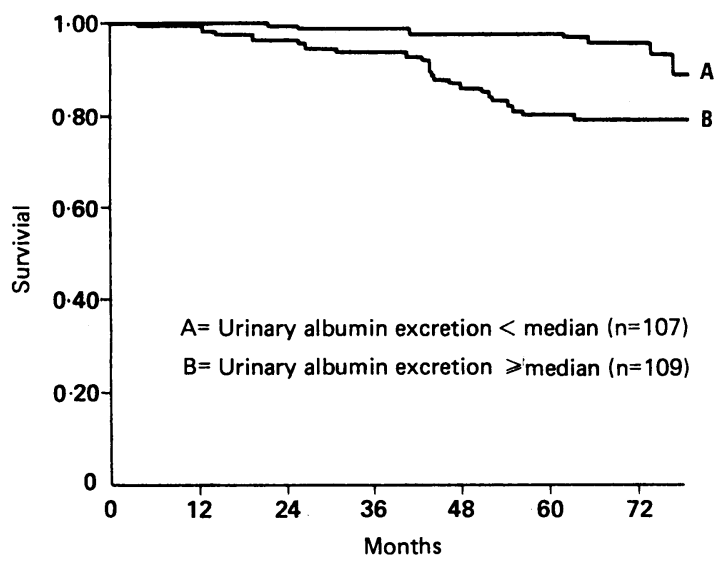

Survival curves for subjects aged 60-74 in municipality of Fredericia Denmark, according to whether urinary albumin excretion rate was below or at or above median value $(7.52 \mathrm{\mu g} / \mathrm{min})$ of 16 who had rates $\geqslant 15.00 \mu \mathrm{g} / \mathrm{min}$. A log rank test showed that male sex, serum creatinine concentration, hypertension, albumin excretion rate, ischaemic heart disease, serum triglyceride concentration, and fasting blood glucose concentration were significantly associated with death (tables III and IV). All risk factors were included in proportional hazards analyses, and albumin excretion, male sex, serum creatinine concentration, and hypertension were then found to be significantly associated with death (table V).

\section{Discussion}

We followed up 223 subjects aged $60-74$ for 62 to 83 months; 35 died. Further analysis showed that three times as many people whose urinary albumin excretion rate was equal to or above the median $(7.52 \mu \mathrm{g} / \mathrm{min})$ died compared with those who had rates below the median. In the Framingham study a cohort aged 50-62 at entry into the study was followed up for 16 years ${ }^{21}$ proteinuria $(\geqslant 0.2 \mathrm{~g} / \mathrm{l})$ increased the mortality threefold. In our study only four people (one of whom died) had an albumin excretion rate above $200 \mu \mathrm{g} / \mathrm{min}$, suggesting that the excess mortality in subjects who had an albumin excretion rate above the median value was not due to proteinuria. Yudkin et al recently reported that microalbuminuria was a strong risk factor in people who are not diabetic. ${ }^{10}$ In their study 24 out of 149 subjects observed for an average of 3.6 years had an albumin excretion rate above $20 \mu \mathrm{g} / \mathrm{min}$ initially; in all, nine subjects died, of whom six had had an excretion rate above $20 \mu \mathrm{g} / \mathrm{min}$. Yudkin et al reported that a urinary excretion rate above $20 \mu \mathrm{g} / \mathrm{ml}$ strongly predicted the presence of ischaemic heart disease and peripheral vascular disease. Their population was younger than ours $(60 v 68)$. In a previous report we discussed the association between microalbuminuria and hypertension in the population described in this paper and found a slight association. ${ }^{9}$

Many risk factors apart from microalbuminuria are supposed to influence morbidity and mortality in diabetics and non-diabetics. We included total cholesterol and high density lipoprotein concentrations in the risk factors we studied as they have been shown to be related to cardiovascular disease in people aged 49 and over. ${ }^{22}$ Low density lipoprotein concentrations are positively associated with coronary artery disease in non-diabetics, ${ }^{23}$ and triglyceride and very low density lipoprotein concentrations may play a part in the development of vascular disease.$^{24} \mathrm{C}$ peptide concentration was included as a risk factor because hyperinsulinaemia is associated with a high prevalence of cardiovascular disease..$^{25-27}$

To evaluate the relative importance of the risk factors in our study log rank tests were performed on each variable. All risk factors were included in a proportional hazards analysis, and albumin excretion, male sex, serum creatinine concentration, and hypertension were found to be significantly associated with death. In a Danish study of the association between microalbuminuria and mortality in non-insulin dependent diabetic patients ${ }^{4}$ a proportional hazards analysis showed that albumin excretion, age, duration of diabetes, and serum creatinine concentration were of significance. It has been suggested that the urinary albumin excretion rate reflects the vascular state of an individual..$^{28}$ In our study, however, more than half of the subjects died from coronary artery disease or cerebrovascular disease or were found dead irrespective of their albumin excretion rate.

In conclusion, the association between urinary albumin excretion rate and mortality that has been described in diabetes mellitus seems also to be present in elderly people in general when other known risk factors are taken into account. 
We thank the statistical office of the municipality of Fredericia for providing the population data and Mrs Rita Moreau for secretarial help. The plasma $C$ peptide analyses were done by the Hagedorn Research Laboratory and lipoprotein analyses by the lipid research laboratory of Allborg Hospital. We also thank Drs Birgit Kvinesdal and Jens Rokkedal Nielsen for coding the electrocardiograms. The work was supported by the Danish Diabetes Association, the Danish Heart Association, and the Vejle County Research Foundation.

1 Mogensen CE, Chachati A, Christensen CK, et al. Microalbuminuria: an early marker of renal involvement in diabetes. Uremia Investigations 1985-6;9: $85-95$

2 Mogensen CE. Microalbuminuria predicts clinical proteinuria and early mortality in maturity-onset diabetes. $N$ Engl $\mathcal{G}$ Med 1984;310:356-60.

3 Jarrett RJ, Viberti CG, Argyropoulos A, et al. Microalbuminuria predicts mortality in non-insulin-dependent diabetes. Diabetic Med 1984;1:17-9.

4 Schmitz A, Vaeth M. Microalbuminuria: a major risk factor in non-insulin dependent diabetes. A 10 -year follow-up study of 503 patients. Diabetic Med 1988;5:126-34.

5 Mattock MB, Keen H, Viberti GC, et al. Coronary heart disease and urinary albumin excretion rate in type 2 (non-insulin-dependent) diabetic patients. Diabetologia 1988;31:82-7.

6 Mogensen CE, Christensen CK. Predicting diabetic nephropathy in insulindependent patients. $N$ Engl $\mathcal{F}$ Med 1984;311:89-93.

7 Viberti G. Etiology and prognostic significance of albuminuria in diabetes. Diabetes Care 1988;11:840-5.

8 Mogensen CE, Schmitz A, Christensen CK. Comparative renal pathophysiology relevant to IDDM and NIDDM patients. Diabetes/Metabolism Review 1988;4:453-83.

9 Damsgaard EM, Mogensen CE. Microalbuminuria in elderly hyperglycaemic patients and controls. Diabetic Med 1986;3:430-5.

10 Yudkin JS, Forrest RD, Jackson CA. Microalbuminuria as predictor of vascular disease in non-diabetic subjects. Lancet 1988;ii:530-3.

11 Damsgaard EM, Frøland A, Green A, Hauge M. An alternative sampling approach to the study of diabetes prevalence. Scand f Soc Med 1984;12: $115-20$

12 Faber $\mathrm{OK}$, Nielsen $\mathrm{OH}$, Beck-Nielsen $\mathrm{H}$, et al. Beta-cell secretion as a measure of insulin dependency in diabetic patients [Abstract]. Acta Endocrinol 1984;Suppl 106:2.
13 Schmidt FH. Enzymatische Teste zur Schnell-Diagnose. In: Beringer A, ed International Donau-symposium diabetes melitus 3. Vienna: Springer Verlag, 1973:567-8.

14 Dyerberg J, Meinertz $\mathrm{H}$. Comparison of determination of plasma lipoprotein concentration by ultracentrifugation and electrophoresis. In: Peeters $\mathrm{H}$, ed. Proteides of the biological fuids (proceedings of the 25th colloquium). New York: Pergamon Press, 1978:419-21.

15 Heding LG. Radioimmunological determination of human C-peptide in serum. Diabetologia 1975;11:541-8.

16 Miles DW, Mogensen CE, Gundersen HJG. Radioimmunoassay for urinary albumin, using a single antibody. Scand f Clin Lab Invest 1970;26:5-11.

17 Rose GA, Blackburn H. Cardiovascular survey methods. Geneva: World Health Organisation, 1968:137-45.

18 Ellestad MH. Stress testing principles and practice. Philadelphia: F A Davis, $1975: 15$

19 Kusumi RK, Grover PJ, Kunin CM. Rapid detection of pyuria by leucocyte esterase activity. FAMA 1981;245:1653-5

20 Cox DR. Regression models and life tables. Journal of the Royal Statistical Society 1972;B34:187-220.

21 Kannel WB, Stampfer MJ, Castelli WP, Verter J. The prognostic significance of proteinuria: the Framingham study. Am Heart 7 1984;108:1347-52.

22 Castelli WP, Garrison RJ, Wilson PWF, et al. Incidence of coronary hear disease and lipoprotein cholesterol levels. FAMA 1986;256:2835-8.

23 Gordon T, Castelli WP, Hjortland MC, et al. High density lipoproteins as a protective factor against coronary heart disease: the Framingham study. Am F Med 1977;62:707-14.

24 Pyörälä $K$, Laakso $M$, Uusitupa $M$. Diabetes and atherosclerosis: an epidemiological view. Diabetes/Metabolism Reviews. 1987;3:436-524.

25 Eschwege E, Richard JL, Thibault N, et al. Coronary heart disease mortality in relation with diabetes, blood glucose and plasma insulin levels. The Paris relation with diabetes, blood glucose and plasma insulin levels. The Par
prospective study, ten years later. Horm Metab Res 1985;suppl 15:41-6.

26 Pyörälä K, Savolainen E, Kaukola S, Haapakoski J. Plasma insulin as coronary yörälä $\mathrm{K}$, Savolainen $\mathrm{E}$, Kaukola $\mathrm{S}$, Haapakoski J. Plasma insulin as coronary
heart disease risk factor: relationship to other risk factor and predictive value during $91 / 2$-year follow-up of the Helsinki policemen study population. Acta Med Scand 1985; suppl 701:38-52.

27 Welborn TA, Wearne $\mathrm{K}$. Coronary heart disease incidence and cardiovascular mortality in Busselton with reference to glucose and insulin concentration. Diabetes Care 1979;2:154-60.

28 Shearman CP, Gosling P. Microalbuminuria and vascular permeability. Lance 1988;ii:906-7.

(Accepted 27 November 1989)
Department of Medicine and Retrovirus Research Group, Northwick Park Hospital and Clinical Research Centre, Harrow HA1 3UJ

J K Cruickshank, MD, senior registrar

J H Richardson, PHD, research fellow

A L Newell, BSC, research officer

P Rudge, FRCP, consultant neurologist

A G Dalgleish, FRACP, head of group

Faculty of Medicine, University of West Indies,

Kingston 7, Jamaica

O St C Morgan, FRCP, professor

J Knight, medical student

Medical School,

University of Oxford,

Oxford

J Porter, medical student

P Klenerman, medical

student

Correspondence to: $\mathrm{Dr}$ Cruickshank.

Br Med f 1990;300:300-4

\section{Screening for prolonged incubation of HTLV-I infection in British and Jamaican relatives of British patients with tropical spastic paraparesis}

J K Cruickshank, J H Richardson, O St C Morgan, J Porter, P Klenerman, J Knight, A L Newell, P Rudge, A G Dalgleish

\section{Abstract}

Objective-To compare the prevalence of antibody to and proviral DNA of the retrovirus HTLV$I$ in relatives of 11 British patients with tropical spastic paraparesis who had migrated from Jamaica before they developed symptoms, and to examine factors possibly related to transmission of HTLV-I.

Design-Migrant, family study. Antibody state was determined by several methods and confirmed by western blotting; the polymerase chain reaction was used to detect proviral DNA.

Setting-Britain and Jamaica.

Subjects-All available first degree relatives: those born and still resident in Jamaica (group 1); those born in Jamaica who migrated to Britain (group 2 ); and index patients' children who were born and resident in Britain (group 3). All had been breast fed and none had had blood transfusions.

Results - Of the 66 living relatives, 60 were traced. Seroprevalence among those born in Jamaica (irrespective of current residence) was $22 \%(10 / 46$; 95\% confidence limits 9 to $34 \%$ ) compared with zero among British born offspring (0/14) and was higher in group 2 at $33 \%(7 / 21 ; 12$ to $55 \%)$ than in group 1 at $12 \%(3 / 25 ; 0$ to $25 \%)$. (Patients in group 1 had the greatest mean age.) Proviral DNA was not detected in any subject negative for HTLV-I antibody, making prolonged viral incubation in those negative for the antibody unlikely.

Conclusion-In this sample factors related to place of birth and early residence were more important in transmission of HTLV-I than maternal or age effects. In areas with a low to moderate prevalence policies of preventing mothers who are carriers of the virus from breast feeding would be premature.

\section{Introduction}

The human $\mathrm{T}$ cell leukaemia lymphoma virus type I (HTLV-I) has been aetiologically related to the adult T cell leukaemia lymphoma syndrome and, more recently, to tropical spastic paraparesis..$^{2-4}$ Both diseases occur primarily in the major areas where HTLV-I is endemic - south western Japan and the Caribbeanbut also develop in migrants from these regions. The cumulative lifetime risk of developing either disease in otherwise healthy people with antibodies against HTLV-I has been estimated at between $2 \%$ and $7 \%$ and rises with age. ${ }^{9-11}$ Oddly, the risk of adult $\mathrm{T}$ cell leukaemia lymphoma is consistently greater in male carriers of HTLV-I than in female carriers, while that of tropical spastic paraparesis is greater in females and reflects the sex ratio of seroprevalence of HTLV-I in the population.

Known routes of HTLV-I transmission include transfusion with infected cellular blood products, sexual activity, and perinatal transmission from mother to child. ${ }^{12-14}$ Whether breast feeding or other perinatal routes are responsible is uncertain but of considerable 